\title{
Gastrointestinal Pathology in Freshwater Fish, Oreochromis niloticus (Linnaeus) Under Almix Exposure
}

Palas Samanta ${ }^{1,2 *}$, Sandipan $\mathrm{Pal}^{3}$, Aloke Kumar Mukherjee ${ }^{4}$, Tarakeshwar Senapati ${ }^{1}$, Debraj Kole ${ }^{1}$ and Apurba Ratan Ghosh ${ }^{1^{*}}$

${ }^{1}$ Ecotoxicology Lab, Department of Environmental Science, The University of Burdwan, Burdwan, West Bengal, India

${ }^{2}$ Division of Environmental Science and Ecological Engineering, Korea University, Anam-dong, Sungbuk-gu, Seoul 02841, Korea

${ }^{3}$ Department of Environmental Science, Aghorekamini Prakashchandra Mahavidyalaya, Bengai, Hooghly, West Bengal, India

${ }^{4} P G$ Department of Conservation Biology, Durgapur Government College, Durgapur, West Bengal, India

\begin{abstract}
Teleostean fish, Oreochromis niloticus was exposed to almix herbicide under field (8 g/acre) and laboratory (66.67 $\mathrm{mg} / \mathrm{l})$ conditions for a period of 30 days. Histological and ultramicroanatomical responses were investigated in stomach and intestine. In stomach, light microscopy displayed damaged Columnar Epithelial Cells (CEC) and mucosal folds, thinning of the top plate and fused mucosal folds under laboratory condition but no such significant alterations were observed except mucus secretion in field study. Electron microscopic observation revealed alterations in epithelial contour, damage in microridge structures and excessive mucin mass over epithelial surface under Scanning Electron Microscopic (SEM) study in both conditions, but the damage was more severe in laboratory study. Transmission Electron Microscopic (TEM) study disclosed severe deformed nucleus and mitochondria, cellular necrosis and severe vacuolation under laboratory study, but comparatively less symptomatic changes were observed in field study. Intestine showed damage in CEC and rupture in intestinal villi in both the conditions under light microscopy, while ultrastructural study showed degenerative changes in CEC and excess mucus secretion in laboratory condition under SEM study. TEM study depicted deformed nucleus and mitochondria, severe vacuolation, and appearance of double layered cell structures in the laboratory condition but no significant alterations were observed under SEM and TEM study in field condition. The present results clearly demonstrated comparatively less pathological lesions under field study than laboratory observations and these responses displayed by the fish species could be considered as bio indicator for evaluating herbicidal toxicosis in aquatic environment.
\end{abstract}

Keywords: Almix; Histopathology; Scanning electron microscopy; Transmission electron microscopy; Stomach; Intestine; O. niloticus

\section{Introduction}

Pesticides and/or herbicides are the most dangerous one to human and animals as they are present and concentrated in the food chain. Use of pesticides and/or herbicides, in one hand, is a beneficial tool for crop protection from the attack of pests to increase the agricultural productivity, in other hand, is a serious concern due to its toxicity, and bioaccumulation and non-biodegradable properties [1]. They are released into the environment and ultimately find their way into aquatic bodies by variety of means such as agricultural run-off, spray drift and/ or aerial spraying, and by effluent discharge from manufacturing unit. This posing threats to the aquatic inhabitants such as shell-fish and finfish, which are of great economic importance to the human society as they are considered as sources of protein rich food [2].

Microscopic observations either through light or electron microscopy are the inevitable tools to measure the toxicity, and contribute to the establishment of measures that aim to monitor environmental contamination, lessening the risk not only to ecosystems, but also to human health. Cellular responses including histopathological observations provides a link to identify changes at sub-organismal level before becoming evident at higher levels of biological organization $[3,4]$, which ultimately provide a better warning signs of potential damage to animal health [5]. Cellular responses are vital tools for the early and sensitive detection of chemical exposure in ecotoxicological study, due to the assumption that cellular changes can ultimately result into ecological change [6,7], although the relationship between the different levels of biological organization is neither straight forward nor deterministic [6]. In this context, pathological responses in different organs of vertebrates and invertebrates have been shown to be useful stress markers that are used to detect the toxic effects on organisms of various anthropogenic pollutants through microscopic observations and finally reflect health status of entire ecosystem [8-10]. Histology is widely used as routine biomarker of xenobiotics, due to its target organ toxicity [9], while Scanning Electron Microscopy (SEM) depicts topological characterization of cell surface and Transmission Electron Microscopy (TEM) discloses the organizational orientation.

In aquatic ecosystem, fish are considered as sentinel organisms for evaluating toxicosis of xenobiotic substances under aquatic environment. Fish occupies the top of the aquatic food chain, are highly visible resource and highly exposed to accumulate these toxic substances [11]. In addition to this, they are in direct contact continuously with these substances in water via their gills and their body surface. Ultrastructural or histological study of the gut epithelium is very prominent diagnostic tool, due to their specific organ toxicity including stomach and intestine as these two organs are responsible for digestion and subsequent absorption of these ingested food materials

${ }^{*}$ Corresponding authors: Palas Samanta, Division of Environmental Science and Ecological Engineering, Korea University, Anam-dong, Sungbuk-gu, Seoul 02841 Republic of Korea, Tel: +821095366822; E-mail: samanta@korea.ac.kr

Apurba Ratan Ghosh, Ecotoxicology Lab, Department of Environmental Science The University of Burdwan, Golapbag, Burdwan 713104, West Bengal, India, Tel: +913422657938; E-mail: apurbaghosh2010@gmail.com

Received August 23, 2016; Accepted August 26, 2016; Published August 30 2016

Citation: Samanta P, Pal S, Mukherjee AK, Senapati T, Kole D, et al. (2016) Gastrointestinal Pathology in Freshwater Fish, Oreochromis niloticus (Linnaeus) Under Almix Exposure J Environ Anal Toxicol 6: 399. doi: 10.4172/2161 0525.1000399

Copyright: () 2016 Samanta P, et al. This is an open-access article distributed under the terms of the Creative Commons Attribution License, which permits unrestricted use, distribution, and reproduction in any medium, provided the original author and source are credited. 
Citation: Samanta P, Pal S, Mukherjee AK, Senapati T, Kole D, et al. (2016) Gastrointestinal Pathology in Freshwater Fish, Oreochromis niloticus (Linnaeus) Under Almix Exposure. J Environ Anal Toxicol 6: 399. doi: 10.4172/2161-0525.1000399

by the intestinal part respectively. The changes in their tissue system after xenobiotic exposure are not only structural but also functional but changes were more easily identifiable than functional ones [12], and serve as better warning signal for animal health status $[13,14]$. Extensive study at sub-cellular level, through histological and micro anatomical observations of Indian freshwater teleostean gut epithelium were reported by several authors [15-18], but the study on surface architecture and ultra-structural responses of gut epithelium to almix exposure was very scanty especially stomach and intestine $[19,20]$ till date. Almix is widely used modern fourth generation herbicide in India. It works both through contact and systematic pathway to control broad leaf weeds selectively in terrestrial and aquatic system. It is a mixture of two herbicides namely metsulfuron methyl (10.1\%) and chlorimuron ethyl (10.1\%), and remaining $79.80 \%$ adjuvants [21]. Our previous study demonstrated that almix herbicide caused biochemical alterations and develops oxidative stress in Oreochromis niloticus [22-28]. It can also be related that the effects can corroborate histopathological alterations due to oxidative stress. Considering this fact, present investigation is concerned with evaluation of histological and ultrastructural responses especially in stomach and intestine of Oreochromis niloticus (Linnaeus) after almix exposure under natural and laboratory conditions.

\section{Materials and Methods}

\section{Fish}

For the present study, freshwater fish Oreochromis niloticus (average weight, $38.6 \pm 2.47 \mathrm{~g}$ and average length, $13.6 \pm 0.496 \mathrm{~cm}$ ) were purchased from local fish farm and brought to the laboratory for acclimatization. Fish were acclimatized for 15 days in big plastic tank $(250 \mathrm{~L})$. During acclimatization, fish were provided continuous aerated water under static water system and experiments were performed at natural photoperiod ( $12 \mathrm{~h}$ light $/ 12 \mathrm{~h}$ dark). Experiments were carried out according to the guidelines of the Animal Care and Use Committee of the University of Burdwan and were approved by the Ethical Committee. Water parameters were assessed as per APHA [29]. Average water parameters during the acclimatization were as follows: temperature, $26.5 \pm 0.127^{\circ} \mathrm{C} ; \mathrm{pH}, 7.94 \pm 0.041$; Electrical Conductivity (EC), $391 \pm 0.624 \mu \mathrm{S} / \mathrm{cm}$; total dissolved solids (TDS), $278 \pm 0.693 \mathrm{mg} / \mathrm{l}$; Dissolved Oxygen (DO), $6.44 \pm 0.052 \mathrm{mg} / \mathrm{l}$; total alkalinity, $205 \pm 7.31$ $\mathrm{mg} / \mathrm{l}$ as $\mathrm{CaCO}_{3}$; total hardness, $179 \pm 3.75 \mathrm{mg} / \mathrm{l}$ as $\mathrm{CaCO}_{3}$; sodium, $24.5 \pm$ $0.563 \mathrm{mg} / \mathrm{l}$; potassium, $5.33 \pm 1.02 \mathrm{mg} / \mathrm{l}$; orthophosphate, $0.032 \pm 0.001$ $\mathrm{mg} / \mathrm{l}$; ammonical-nitrogen, $1.66 \pm 0.212 \mathrm{mg} / \mathrm{l}$; and nitrate-nitrogen, $0.212 \pm 0.030 \mathrm{mg} / \mathrm{l}$. Fish, after 15 days of acclimatization, were divided into two equal sets: one set of fish was transferred to the ponds situated at the Crop Research and Seed Multiplication Farm (CRSMP) premises of the University of Burdwan, and another set of fish was brought to the glass aquarium. Commercial fish pellets ( $32 \%$ crude protein, Tokyu) were given to the fish as food during both acclimation and exposure periods.

\section{Field experiment}

Field set of fish were again segregated into two equal parts and transferred to the cages (triplicate) installed at control and treatment ponds. Each cage contains 10 fish species. Almix herbicide (dose 8 $\mathrm{g} / \mathrm{acre}$ ) was dissolved in water at field recommended dose for rice cultivation and was sprayed on first day in treated pond [24,25,28]. Duration of the experiment was 30 days. For culturing the fish species, special type of cage was prepared and was installed at the middle of the respective ponds based on Chattopadhyay et al. [30] with some modifications. Cages were rectangular in shape. The area of each cage was approximately $2.5 \mathrm{~m} \times 1.22 \mathrm{~m}$ (length and width) and height of approximately $1.83 \mathrm{~m}$ (submerged height in pond water, $0.83 \mathrm{~m}$ ). Cages were structured by strong bamboo. Four-sided wall, cage floor and top of the cage cover were prepared by two polyvinyl chloride (PVC) nets: the inner and outer net bearing the mesh size of $1.0 \times 1.0 \mathrm{~mm}^{2}$ and $3.0 \times 3.0 \mathrm{~mm}^{2}$, respectively. During field experimentation period, water parameters showed the following average values: temperature, $24.1 \pm 0.203^{\circ} \mathrm{C} ; \mathrm{pH}, 6.56 \pm 0.086$; Electrical Conductivity (EC), $348 \pm$ $1.16 \mu \mathrm{S} / \mathrm{cm}$; Total Dissolved Solids (TDS), $248 \pm 1.46 \mathrm{mg} / \mathrm{l}$; Dissolved Oxygen (DO), $6.99 \pm 0.158 \mathrm{mg} / \mathrm{l}$; total alkalinity, $222 \pm 3.54 \mathrm{mg} / \mathrm{l}$ as $\mathrm{CaCO}_{3}$; total hardness, $142 \pm 2.32 \mathrm{mg} / \mathrm{l}$ as $\mathrm{CaCO}_{3}$; sodium, $63.4 \pm 2.68$ $\mathrm{mg} / \mathrm{l}$; potassium, $15.9 \pm 2.11 \mathrm{mg} / \mathrm{l}$; orthophosphate, $0.243 \pm 0.025 \mathrm{mg} / \mathrm{l}$; ammonical-nitrogen, $0.741 \pm 0.111 \mathrm{mg} / \mathrm{l}$; and nitrate-nitrogen, $1.66 \pm$ $0.035 \mathrm{mg} / \mathrm{l}$.

\section{Laboratory experiment}

Laboratory fishes were again segregated into two sets; one set for control and another set for treatment. Both sets comprise of three aquariums ( $40 \mathrm{~L}$ ) and each aquarium contains 10 fish species. Experiment was performed at Ecotoxicology Lab, Department of Environmental Science, the University of Burdwan. Fish were intoxicated at sublethal dose of almix (i.e., $66.67 \mathrm{mg} / \mathrm{l}$ ) and duration of the experiment was 30 days $[22,23,26,27]$. Dose was applied every alternate day. Average water parameters during the experimentation period showed the following values: temperature, $26.6 \pm 0.120^{\circ} \mathrm{C} ; \mathrm{pH}, 7.93 \pm 0.076$; Electrical Conductivity (EC), $425 \pm 5.94 \mu \mathrm{S} / \mathrm{cm}$; Total Dissolved Solids (TDS), 303 $\pm 4.68 \mathrm{mg} / \mathrm{l}$; Dissolved Oxygen (DO), $5.06 \pm 0.432 \mathrm{mg} / \mathrm{l}$; total alkalinity, $210 \pm 10.5 \mathrm{mg} / \mathrm{l}$ as $\mathrm{CaCO}_{3}$; total hardness, $164 \pm 3.05 \mathrm{mg} / \mathrm{l}$ as $\mathrm{CaCO}_{3}$; sodium, $37.8 \pm 1.03 \mathrm{mg} / \mathrm{l}$; potassium, $7.26 \pm 1.12 \mathrm{mg} / \mathrm{l}$; orthophosphate, $0.041 \pm 0.002 \mathrm{mg} / \mathrm{l}$; ammonical-nitrogen, $7.09 \pm 2.15 \mathrm{mg} / \mathrm{l}$; and nitratenitrogen; $1.78 \pm 0.263 \mathrm{mg} / \mathrm{l}$.

\section{Histopathological analysis}

After completion of the experiment i.e., 30 days, fish were collected both from lab aquarium and field ponds, and were anesthetized by using tricaine methanesulphonate (MS 222). After anesthetization, desired organs (stomach and intestine) were taken after dissection and washed with $0.75 \%$ saline solution, fixed with specific fixatives, and finally proceeded accordingly.

For histological observation, stomach and intestine were fixed in aqueous Bouin's solution. After fixation excess Bouin's were removed with $70 \%$ alcohol, then dehydrated through different graded ethanol solution, and tissues were infiltrated and embedded in paraffin and paraffin blocks were prepared. Then, Leica RM2125 microtome was used to cut paraffin sections at 3-4 micron and sections were placed on slide. Finally, paraffin sections were stained with haematoxylin-eosin (H\&E) staining procedure and pathological lesions were examined under light microscope (Leica DM2000) and photographs were taken.

\section{Ultramicroscopic analysis}

For Scanning Electron Microscopic (SEM) observations, tissues were first fixed in $2.5 \%$ glutaraldehyde solution (prepared in $0.2 \mathrm{M}$ of $\mathrm{pH} 7.4$ phosphate buffer) at $4^{\circ} \mathrm{C}$ for $24 \mathrm{~h}$. After $24 \mathrm{~h}$, tissues were again post-fixed with $1 \%$ osmium tetraoxide at $4^{\circ} \mathrm{C}$ for $2 \mathrm{~h}$. Then, tissues were dehydrated through different graded acetone solution, followed by amyl acetate solution and finally, tissues were subjected to drying at Critical Point Dryer (CPD) using liquid carbon dioxide. After drying, tissues were cut into small pieces and mounted on metal stubs by using tape and finally coated with gold (thickness approx. $20 \mathrm{~nm}$ ). Tissues were then scanned under scanning electron microscope (Hitachi S-530) to identify the alterations at University Science Instrumentation Centre, 
Citation: Samanta P, Pal S, Mukherjee AK, Senapati T, Kole D, et al. (2016) Gastrointestinal Pathology in Freshwater Fish, Oreochromis niloticus (Linnaeus) Under Almix Exposure. J Environ Anal Toxicol 6: 399. doi: 10.4172/2161-0525.1000399

the University of Burdwan, West Bengal, India and photographs were taken.

In case of TEM study, tissues were fixed in Karnovsky fixative solution at $4^{\circ} \mathrm{C}$ for $12 \mathrm{~h}$. After this fixation, tissues were again post-fixed with $1 \%$ osmium tetraoxide for $2 \mathrm{~h}$ at $4^{\circ} \mathrm{C}$. Then tissues were washed with phosphate buffer solution ( $0.2 \mathrm{M}$ and $\mathrm{pH} 7.4)$ and dehydrated through different graded acetone solution, then infiltrated and embedded in epoxy resin (araldite CY212). Ultrathin sections (thickness approx. 70 $\mathrm{nm}$ ) were then cut on "Ultracut E Reichart - Jung" machine. Glass knife was used for cutting the ultrathin sections. Sections were collected on naked copper-meshed grids, and finally contrasted with uranyl acetate followed by lead citrate. Finally, stained sections were observed under transmission electron microscope (TECHNAI G2) at Electron Microscope Facility, Department of Anatomy, AIIMS, New Delhi, India and photographs were taken.

\section{Results}

\section{Stomach}

Most prominent alterations in stomach of O. niloticus in the laboratory condition after almix exposure were damage in columnar epithelial cells (CEC) and mucosal folds, top plate thinning, fused mucosal folds and also damage in submucosa (Figure 1.2) compared with control one (Figure 1.1), but in field condition there was slight mucus secretion from mucosa layers, and the structure mostly appeared to be normal like control condition (Figure 1.3).

Scanning electron microscopic observation showed ultra-structural lesions such as alteration of epithelial cells contour, loss and damage of micro ridge structures and appearance of mucin mass over epithelial surface under both the conditions, but the degree of responses was more severe under laboratory observation (Figures 1.4-1.6).

Transmission electron microscopic observation of stomach of $O$. niloticus showed severe deformed nucleus and mitochondria, cellular necrosis and severe vacuolation under laboratory condition (Figure 1.8) in comparison to control findings (Figure 1.7), while in field condition dilated mitochondria and vacuolations were prominent but alterations were less than laboratory condition (Figure 1.9).

\section{Intestine}

The major histopathological changes associated with intestinal epithelium of $O$. niloticus under laboratory study after almix
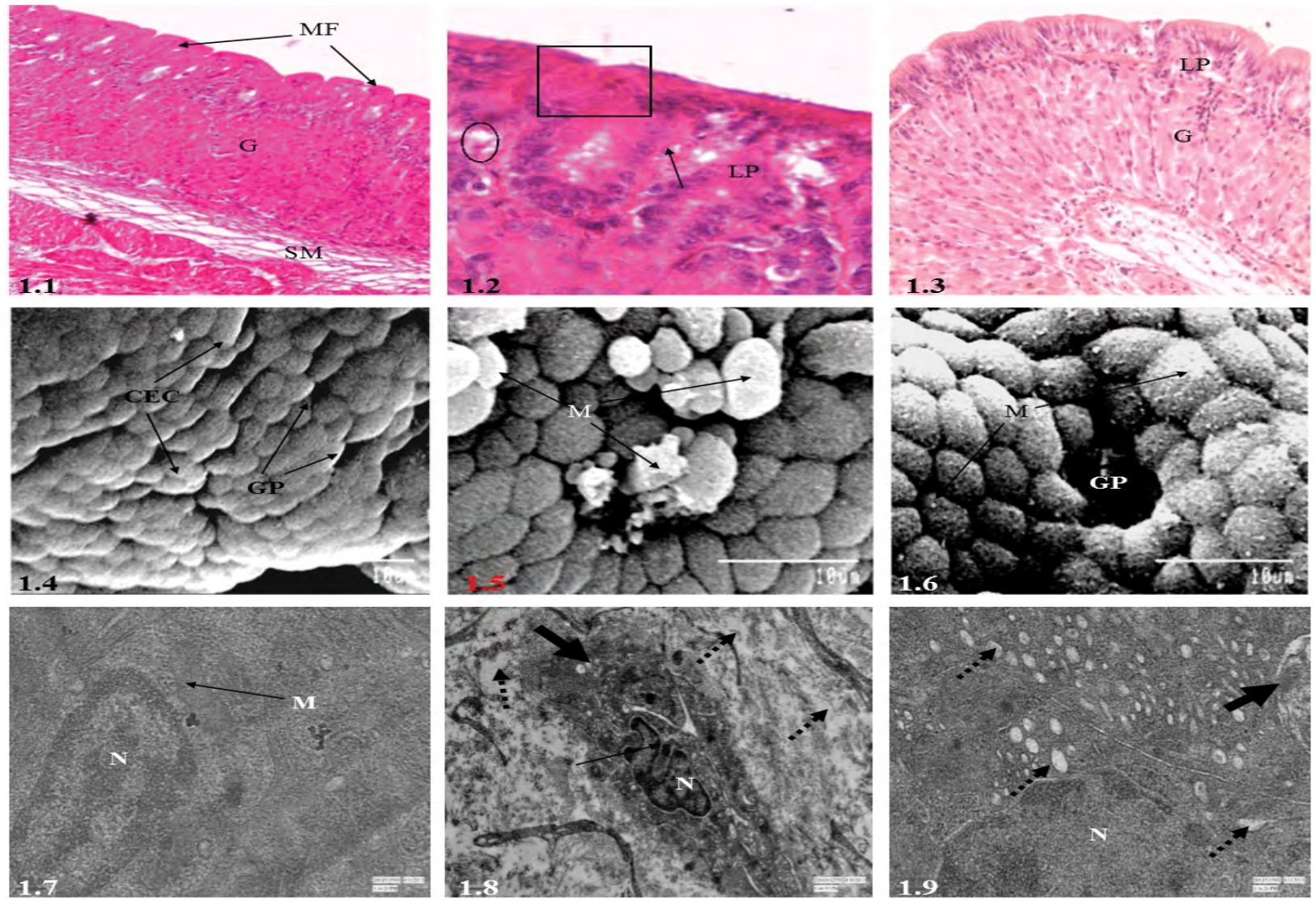

Figure 1: Pathological micrograph of stomach of $O$. niloticus at control $(C)$, laboratory condition $(A L)$ and field condition (AF). $1.1 \mathrm{Showing}$ normal columnar epithelial cell (CEC), lamina propria (LP), gastric gland (GG) and sub-mucosa (SM) under light microscopy (Cx1000); 1.2 showing fused mucosal folds (square), damaged lamina propria (oval) and CEC (arrow) (ALx400); 1.3 showing normal and compact arrangement of CEC with distinct nucleus under normal microscopy (AFx400); 1.4 showing normal and regular mucosal folds (MF) surrounded by oval or rounded CEC with stubby microvilli (MV) and gastric pits (GP) under SEM study (Cx3000); 1.5 showing severe mucus secretion on CEC (arrow) and irregular shape of CEC under SEM (ALx4000); 1.6 showing normal muscosal folds and CEC under SEM (AFx4000); 1.7 showing normal and regular GG and nucleus (N) with distinct mitochondria (M) under TEM (Cx9900); 1.8 showing deformation in nucleus (arrow) and mitochondria (bold arrow), and vacuolation in cytoplasm (broken arrow) under TEM study (ALx2550); and 1.9 showing dilation in mitochondria (bold arrow) and vacuolation (broken arrow) under TEM observation (AFx9900). 
Citation: Samanta P, Pal S, Mukherjee AK, Senapati T, Kole D, et al. (2016) Gastrointestinal Pathology in Freshwater Fish, Oreochromis niloticus (Linnaeus) Under Almix Exposure. J Environ Anal Toxicol 6: 399. doi: 10.4172/2161-0525.1000399

Page 4 of 6

intoxication was distortion in columnar epithelial cells and rupture in intestinal villi (Figure 2.2). On the other hand, connective tissues of the lamina propria showed distortion and rupture in the tip of the intestinal villi under field condition (Figure 2.3).

In our study, SEM observation displayed severe degenerative changes in CEC and excess mucus secretion in laboratory study (Figure 2.5) compared with control findings (Figure 2.4), while appearance of mucin mass over CEC and damaged mucosal folds in some part were the prominent changes under field condition after almix intoxication (Figure 2.6).

TEM observation of intestine displayed distorted nucleus, deformed mitochondria, severe vacuolations, and appearance of double layered cell structures as well as zig-zag pattern tight junction under laboratory condition after almix exposure (Figure 2.8) compared with control (Figure 2.7), while in field condition the intestinal epithelium showed almost normal appearance along with normal structure of glycocalyx and vast amount of mitochondria (Figure 2.9).

\section{Discussion}

Present investigation first time reporting the toxicity of commercial herbicide, almix with regard to histological and ultramicroscopical observations in Indian freshwater teleost, O. niloticus both under field and laboratory study. Although Senapati et al. [19,20] postulated pathological lesions in oesophagus, buccopharynx, and some part of gastrointestinal tract (GIT) namely stomach and intestine of $A$. testudineus after almix intoxication under laboratory observation. In addition, Samanta et al. [22-28] demonstrated toxicity on biochemical parameters in different Indian cat fish species including O. niloticus under laboratory and field observations.

Present study revealed that $O$. niloticus was exposed to almix herbicide for 30 days and showed varied cytopathological alterations in different parts of GIT namely stomach and intestine under field and laboratory observations. Fish stomach is primarily responsible for the digestion of ingested food materials and is vital organ, which is affected by different xenobiotic compounds. In our findings, stomach showed degenerative changes like distorted mucosal folds, damage in CEC and submucosa, top plate thinning and merged mucosal folds in the laboratory study. Similar observations reported in our study was also supported by the findings of Haque et al. [31] in stomach of Channa punctatus exposed to sodium fluoride and this might be due to organochloride acid formation in stomach from the cardiac stomach and this acid caused the abovementioned abnormalities by destroying mucus secreting cells present in the gastric epithelium. Haloi et al. [32]
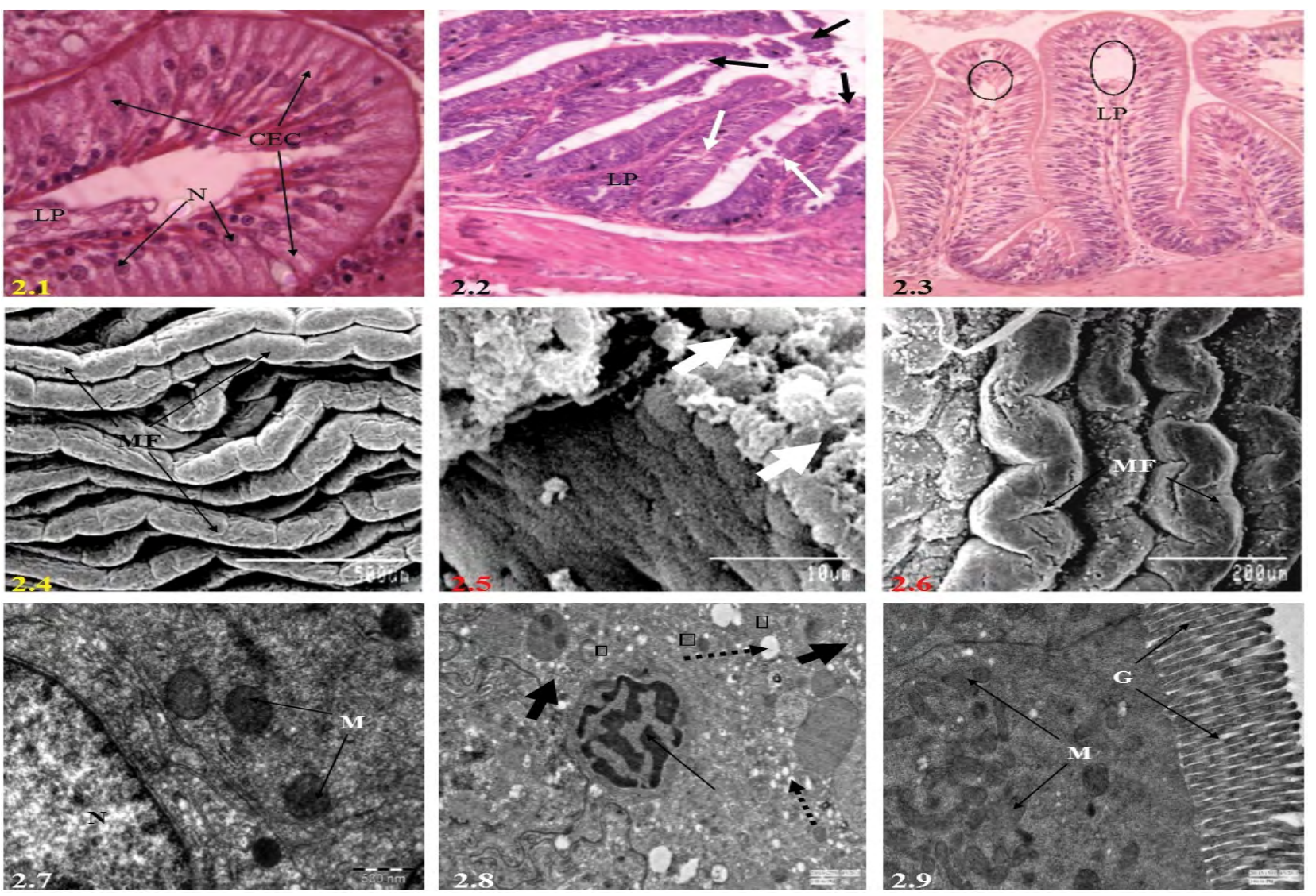

Figure 2: Pathological micrographs of intestine of $O$. niloticus at control condition (C), laboratory condition (AL) and field condition (AF). 2.1 showing normal lamina propria (LP), and CEC with distinct nucleus under light microscopy (Cx1000); 2.2 showing damaged CEC (white arrow) and distortion of villi (black arrow) (ALx400); 2.3 showing only distortion in lamina propria (oval) in normal microscopy (AFx400); 2.4 showing normal and regular mucosal folds supported by oval or rounded CEC under SEM study (Cx80); 2.5 showing degeneration of CEC)(bold arrow) (ALx4000); 2.6 showing damage only in MV (arrow) under SEM (AFx200); 2.7 showing normal and regularly arranged CEC with distinct mitochondria (M) and nucleus (N) under TEM (Cx8000); 2.8 showing deformative changes in nucleus (arrow) and mitochondria (bold arrow), vacuolated cytoplasm (broken arrow) and presence of double-layered cell structures (square) under TEM (ALx2550); and 2.9 showing normal epithelial cells and glycocalyx (G) with abundant mitochondria (M) under TEM observation (AFx5000). 
Citation: Samanta P, Pal S, Mukherjee AK, Senapati T, Kole D, et al. (2016) Gastrointestinal Pathology in Freshwater Fish, Oreochromis niloticus (Linnaeus) Under Almix Exposure. J Environ Anal Toxicol 6: 399. doi: 10.4172/2161-0525.1000399

Page 5 of 6

in their study observed fusion of stomach microvilli, pigmentation in different parts of the microvilli, appearance of vacuolation, cell swelling, aggregation of blood cells and haemorrhage after endosulfan exposure in stomach of $C$. punctatus. Degenerative changes in CEC, vacuolations in gastric epithelium and distortion in gastric glands was also demonstrated by Senapati et al. [20] after almix exposure but in stomach of Anabas testudineus. Therefore, the pathological alterations observed under present study may be associated with the response of stomach to the herbicidal contamination resulting into alterations of different biochemical pathways. Presence of mucin mass over gastric epithelium seen under field observation indicates the compensatory response displayed by fish against stress condition. Scanning electron microscopy of gastric mucosa showed damage in epithelial cells, loss of microridge structures and appearance of large amount of mucin mass over gastric epithelium, resulting in reduction of protective ability of the gastric epithelium toward such injury caused by herbicide exposure under both the conditions but the degree of pathogenicity was much more severe in laboratory condition. Disruptions of microridge structures seen under present study can reduce the retention ability of mucus film, which ultimately impair ingestion of food materials and subsequent transfer to the next region and ultimately deteriorate fish health. Furthermore, excessive mucus secretion to almix intoxication indicates enhanced activity of abovementioned cells. Similar findings was also noticed by Senapati et al. [19] in A. testudineus after almix herbicide exposure and with the findings of Haque et al. [31] who observed similar symptoms in C. punctatus to sodium fluoride exposure. Vacuolations in gastric epithelium seen under TEM observation indicated inhibition of protein synthesis and energy depletion [33]. Deformed nucleus and mitochondria, and cellular necrosis are also prominent, which indicates toxic stress development. Degenerative changes in mitochondria observed under present investigation might impair the oxidative capability by regulating the functions of normal respiratory enzymes during metabolism of metabolism and synthesis of fatty acid. On contrary, Carrassón et al. [34] demonstrated presence of large number of both smooth and rough Endoplasmic Reticulum (ER), mitochondria, tubule-vascular network and heterochromatinic nucleus in Dentex dentex. Therefore, the pathological responses observed in the present study were more severe in laboratory study and comparatively less pathological lesions under field fish might be due to self-regulating capacity of natural aquatic environment and diluted action of herbicide by natural condition as well as by metabolic adaptation in the natural environment.

Intestine is the next important part of GI tract after stomach. It plays an important role in digestion process and subsequent absorption of food stuffs. In addition, serves as potent organ for evaluating toxicity of contaminants as they enter into the fish body directly via gill surface and intake of contaminated foods or indirectly via skin or blood $[35,36]$. Present study revealed that $O$. niloticus exposed to almix herbicide showed severe histopathological changes such as damage in CEC, lamina propria and rupture in intestinal villi under both conditions, but the severity of pathological lesions was more prominent under laboratory study. Present findings were supported by Soufy et al. [37] and these may be due to absorption of contaminated food materials by intestinal epithelium. Koaud et al. [38] observed atrophy in muscularis and submucosa, degenerative and necrotic changes in intestinal mucosa and submucosa, and oedema in intestine of O. niloticus after cadmium exposure. Similar findings were also observed by Muley et al. [39] who demonstrated degeneration and rupture in intestinal villi, distortion in mucosal folds, and degenerative submucosa in $C$. punctatus after carbofuran intoxication. In our SEM study, excessive secretion of mucin mass was more notable observation under both the conditions which indicates enhanced protection ability against the ingestion of herbicide molecules through food, and may alter luminal $\mathrm{pH}$ as well as affects the enzymatic breakdown of the polymer substances in intestine and subsequently impair the physiology of digestion $[19,40]$. Degeneration in CEC were also prominent in the laboratory study and results were also supported by Begum and Sengupta [41] who reported fragmented, degenerated epithelium, lesions in columnar epithelial cells and disarrangement of mucosal folds in the intestine of $C$. punctatus after mercury exposure. Senapati et al. [19] also noticed similar observations in intestine of $A$. testudineus exposed to almix herbicide. SEM study also confirmed that alterations were also pronounced in the laboratory observation in comparison to field study and might impair the digestive physiology of the fish species which ultimately lead to impaired fish growth. Under TEM study, deformed nucleus and mitochondria, vacuolations and appearance of double layered cell structures as well as zig-zag pattern of tight junction were the prominent responses to almix exposure under laboratory observation, but no prominent alterations were observed in field study. Begum and Sengupta [41] also noticed similar findings in intestine of C. punctatus after mercury exposure. Appearance of vacuolations in the intestinal epithelium indicates impairment in several biochemical processes including digestive physiology and may lead to damage to the surrounding tissues [42] due to entry of the herbicide into the GI tract, and subsequent alterations in the luminal environment.

\section{Conclusion}

In conclusion, it can be inferred that almix exposure caused pathological alterations in the gastrointestinal tract namely in stomach and intestine, and is toxic to fish. The responses displayed by the concerned fish organs were comparatively less in field study than laboratory study and these responses could be used as biomarkers for evaluating the toxicosis of these agrochemicals and its use in aquatic environment and agricultural fields should be handled very carefully.

\section{Acknowledgements}

The authors like to thank the INSPIRE Program Division, Department of Science and Technology, Govt. of India (DST/INSPIRE Fellowship/2011/164, Dt 29.09.2011) for the financial assistance. We also like to thank the Head, Department of Environmental Science, the University of Burdwan, Burdwan, West Bengal, India for providing the laboratory facilities and library facilities during the course of research.

\section{References}

1. Joseph B, Raj SJ (2010) Effect of curacron toxicity on the total serum protein content of Cyprinus carpio. Toxicol Environ Chem 92: 1889-1893.

2. Rand GM (1995) Fundamentals of Aquatic Toxicology: Effects, Environmental Fate and Risk Assessment. Taylor \& Francis, Washington DC, USA

3. Adams SM, Shepard KL, Greeley MS, Jimenez BD, Ryon MG, et al. (1989) The use of bioindicators for assessing the effects of pollutant stress on fish. Mar Environ Res 28: 459-464.

4. Adams SM, Giesy JP, Tremblay LA, Eason CT (2001) The use of biomarkers in ecological risk assessment: recommendations from the Christchurch conference on Biomarkers in Ecotoxicology. Biomarkers 6: 1-6.

5. Triebskorn R, Köhler HR, Honnen W, Schramm M, Adams SM, et al. (1997) Induction of heat shock proteins, changes in liver ultrastructure, and alterations of fish behavior: are these biomarkers related and are they useful to reflect the state of pollution in the field? J Aquat Ecosyst Stress Recovery 6: 57-73.

6. Segner H, Braunbeck T (1998) Cellular response profile to chemical stress Ecotoxicology 3: 521-569.

7. Wester PW, van der Ven LTM, Vethaak AD, Grinwis GCM, Vos JG (2002) Aquatic toxicology opportunities for enhancement through histopathology. Environ Toxicol Pharmacol 11: 289-295. 
Citation: Samanta P, Pal S, Mukherjee AK, Senapati T, Kole D, et al. (2016) Gastrointestinal Pathology in Freshwater Fish, Oreochromis niloticus (Linnaeus) Under Almix Exposure. J Environ Anal Toxicol 6: 399. doi: 10.4172/2161-0525.1000399

8. Triebskorn R, Köhler HR, Zahn T, Vogt G, Ludwig M, et al. (1991) Invertebrate cells as targets for hazardous substances. Z Angew Zool 78: 277-287.

9. Schwaiger J, Wanke R, Adam S, Pawert M, Honnen W, et al. (1997) The use of histopathological indicators to evaluate contaminant-related stress in fish. $J$ Aquat Ecosyst Stress Recovery 6: 75-86.

10. Kammenga JE, Dallinger R, Donker MH, Kohler HR, Simonsen V, et al. (2000) Biomarkers in terrestrial invertebrates for ecotoxicological soil risks assessment. Rev Environ Contam Toxicol 164: 93-147.

11. Streit B (1998) Bioaccumulation of contaminants in fish. In: Fish Ecotoxicology. Braunbeck T, Hinton DE, Streit B (eds.). Birkhauser, Basel, pp: 353-387.

12. Fanta E, Rios FS, Romão S, Vianna ACC, Freiberger S (2003) Histopathology of the fish Corydoras paleatus contaminated with sublethal levels of organophosphorus in water and food. Ecotoxicol Environ Saf 54: 119-130.

13. Hinton DE, Lauren DJ, Holliday TL, Giam CS (1990) Liver structural alterations accompanying chronic toxicity in fishes: Potential biomarkers of exposure. In: Preprints of Papers Presented at National Meeting, Division of Water, Air and Waste Chemistry, American Chemical Society; (USA) 28: 2; Conference: JAERI/EPA workshop on residual radiation and recycle criteria, St. Michaels MD (USA), 27-28 Sep 1989.

14. Sorour J (2001) Ultrastructural variations in Lethocerus niloticum (Insecta: Hemiptera) caused by pollution in Lake Mariut, Alexandria, Egypt. Ecotoxicol Environ Saf 48: 268-274.

15. Thophon S, Kruatrachue M, Upatham ES, Pokethitiyook P, Sahaphong S, et al (2003) Histopathological alterations of white seabass, Lates calcarifer, in acute and subchronic cadmium exposure. Environ Pollut 121: 307-320.

16. Pandey S, Parvez S, Ansari RA, Ali M, Kaur M, et al. (2008) Effects of exposure to multiple trace metals on biochemical, histological and ultrastructural features of gills of a freshwater fish, Channa punctata Bioch. Chem Biol Interact 174 183-192.

17. Biagini FR, David JAO, Fontanetti CS (2009) The use of histological, histochemical and ultramorphological techniques to detect gill alterations in Oreochromis niloticus reared in treated polluted waters. Micron 40: 839-844.

18. Kasherwani D, Lodhi HS, Tiwari KJ, Shukla S, Sharma UD (2009) Cadmium toxicity to freshwater Catfish, Heteropneustes fossilis (Bloch). Asian J Exp Sci 23: 149-156.

19. Senapati T, Mukherjee AK, Ghosh AR (2012) Observations on the effect of Almix 20WP herbicide on ultrastructure (SEM) in different regions of alimentary canal of Anabas testudineus (Cuvier). Int J Food Agricul Vet Sci 2: 32-39.

20. Senapati T, Samanta P, Mandal S, Ghosh AR (2013) Study on histopathological, histochemical and enzymological alterations in stomach and intestine of Anabas testudineus (Cuvier) exposed to Almix 20WP herbicide. Int J Food Agricul Vet Sci 3: 100-111.

21. DuPont Safety Data Sheet (2012) DuPont ${ }^{\mathrm{TM}}$ Almix $^{\circledR} 20$ WP. Version 2.1.

22. Samanta P, Pal S, Mukherjee AK, Senapati T, Ghosh AR (2014) Effects of Almix herbicide on metabolic enzymes in different tissues of three teleostean fishes Anabas testudineus, Heteropneustes fossilis and Oreochromis niloticus. Int J Sci Res Environ Sci 2: 156-163.

23. Samanta P, Pal S, Mukherjee AK, Senapati T, Ghosh AR (2014) Alterations in digestive enzymes of three freshwater teleostean fishes by Almix herbicide: A comparative study. Proc Zool Soc 69: 61-66.

24. Samanta P, Pal S, Mukherjee AK, Senapati T, Kole D, et al. (2014) Effects of Almix herbicide on alanine aminotransferase (ALT), aspartate aminotransferase (AST) and alkaline phosphatase (ALP) of three teleostean fishes in rice field condition. Global J Environ Sci Res 1: 1-9.

25. Samanta P, Pal S, Mukherjee AK, Senapati T, Kole D, et al. (2014) Effects of Almix herbicide on profile of digestive enzymes of three freshwater teleostean fishes in rice field condition. Toxicol Rep 1: 379-384.

26. Samanta P, Pal S, Mukherjee AK, Ghosh AR (2014) Biochemical effects of almix herbicide in three freshwater teleostean fishes. In: HydroMedit-2014, Volos, Greece, pp: 168-174

27. Samanta P, Pal S, Mukherjee AK, Senapati T, Ghosh AR (2015) Evaluation of enzymatic activities in liver of three teleostean fishes exposed to commercial herbicide, Almix 20 WP. Proc Zool Soc 68: 9-13.

28. Samanta P, Pal S, Mukherjee AK, Senapati T, Kole D, et al. (2016) Effects of Almix ${ }^{\circledR}$ herbicide on oxidative stress parameters in three freshwater teleostean fishes in natural condition. Biochem Pharmacol (Los Angel) 5: 209.
29. APHA, AWWA, WPCF (2005) Standard methods for the examination of water and wastewater. APHA, AWWA, WPCF, Washington DC.

30. Chattopadhyay DN, Mohapatra BC, Adhikari S, Pani PC, Jena JK, et al. (2013) Effects of stocking density of Labeo rohita on survival, growth and production in cages. Aquacult Int 21: 19-29.

31. Haque S, Pal S, Mukherjee AK, Ghosh AR (2012) Histopathological and ultramicroscopic changes induced by fluoride in soft tissue organs of the airbreathing teleost, Channa punctatus (Bloch). Fluoride 43: 263-273.

32. Haloi K, Kalita M, Nath R (2013) The study on the histopathological changes of stomach of Channa punctatus (Bloch). By used pesticide endosulfan. Global J Sci Front Res Biol Sci 13.

33. Rebolledo IM, Vial JD (1979) Fine structure of the oxynticopeptic cell in the gastric glands of Elasmobranch species (Halaelurus chilensis). Anat Rec 193 805-822.

34. Carrassón M, Grau A, Dopazo LR, Crespo S (2006) A histological histochemical and ultrastructural study of the digestive tract of Dentex dentex (Pisces, Sparidae). Histol Histopathol 21: 579-593.

35. Banerjee S, Bhattacharya S (1995) Histopathological changes induced by chronic nonlethal levels of elsan, mercury, and ammonia in the small intestine of Channa punctatus. Ecotoxicol Environ Saf 31: 62-68.

36. Muniyan M (1999) Effect of ethofennprox (trebon) on the biochemical and histological changes in the selected tissues of the freshwater fish, Oreochromis mossambicus (Peters). Ph D Thesis, Annamalai University, India.

37. Soufy H, Soliman MK, El-Manakhy EM, Gaafar AY (2007) Some biochemical and pathological investigations on monosex tilapia following chronic exposure to carbofuran pesticides. Global Vet 1: 45-52.

38. Koaud HA, Zaki MM, El-Dahshan AR, SaeidSh EL, Zorba HY (2011) Amelioration the toxic effects of cadmium exposure in Nile tilapia (Oreochromis niloticus) by using Lemna gibba L. Life Sci J 8: 185-195.

39. Muley DV, Kambale GB, Gaikwad PT (1996) Endosulfan toxicity in the freshwater fish, Tilapia mossambica. Proc Acad Environ Biol 5: 49-55.

40. Ghosh AR (1991) Arsenic and cadmium toxicity in the alimentary canal and digestion of two Indian air-breathing teleosts Notopterus notopterus (Pallas) and Heteropneustes fossilis (Bloch). PhD Thesis, The University of Burdwan, West Bengal, India.

41. Begum M, Sengupta M (2014) Effects of mercury on the activities of antioxidant defences in intestinal macrophages of fresh water teleost Channa punctatus (Bloch 1793). Int J Fisheries Aquat Studies 2: 172-179.

42. Ba Omar TA, Victor R, Tobias DB (1998) Histology of the stomach of Aphanius dispar (Rüppell 1828), a cyprinodont fish, with emphasis on changes caused by stress from starvation. Trop Zool 11: 11-17. 